International Journal of Innovative Studies in Aquatic Biology and Fisheries

Volume 5, Issue 4, 2019, PP 21-31

ISSN 2454-7662 (Print) \& ISSN 2454-7670 (Online)

DOI: http://dx.doi.org/10.20431/2454-7670.0504005

www.arcjournals.org

\title{
Featherback Fishery in Barito Kuala District, Indonesia: Potency, Business Opportunity and Challenge
}

\author{
Ahmadi $^{1}$, Muhammad ${ }^{2}$, Dewi Kartika Sari ${ }^{3}$ \\ Faculty of Marine and Fisheries, Lambung Mangkurat University
}

*Corresponding Author: Muhammad, Faculty of Marine and Fisheries, Lambung Mangkurat University, Banjarbaru 70714, South Kalimantan, Indonesia.

\begin{abstract}
Barito Kuala District is the largest producer of the featherback (Notopterus chitala) in South Kalimantan Province, Indonesia. It contributes about $42.29 \%$ of total regional fisheries production. Recently, supply and demand of raw material for fish chips processing business is completely dependent on the catch from the rivers. Ironically the capture fishery production for featherback tends to decline, which absolutely affecting on production volume and selling expense of the fish products. No commercial aquaculture supports this business, so far. Data on capture fishery, fish processing business and fish farming were tabulated and analyzed using descriptive method. There was a great market opportunity for featherback chips in this area of study, where the demand of fish chips (36 tons/year) was six times higher than the supply to the market (6 tons/year). The average annual profit received by the producer was USD 897. The Net Present Value (NPV), Internal Rate of Return (IRR), and Net Benefit Cost Ratio (Net B/C) were USD 2,796, 137\%, and 4.59 with the Payback Period $(P P)$ value was 8 months 15 days, indicating business was considered feasible and profitable, as well as has the favorable prospect. To increase the values, the culture business should be promoted. An attempt was made by Freshwater Fish Culture Center Mandiangin to culture them; however, the result are still being challenged to overcome this problem. The ideal interconnection of the three key issues was further discussed.
\end{abstract}

Keywords: Featherback, Business feasibility, Interdependence of interest, Barito Kuala District.

\section{INTRODUCTION}

Barito Kuala District is one of the prominent fisheries production areas in South Kalimantan Province, which covers the river of $120 \mathrm{~km}$ and costal line of $14.2 \mathrm{~km}$. Statistically it contributes about $42.29 \%$ of regional fisheries production in 2018. Total number of capture fishery and aquaculture households in Barito Kuala District was 5,335 and 1,569 respectively [1].Fishing and aquaculture activities are being done by local people along the river and costal line. Fish farming areas consisted of brackish water 4,066 ha, pond 29.70 ha, fish cage 408 ha, floating net 7,181 ha and paddy field 11.23 ha, but none of those areas is being used for the featherback fish farming. It is unquestionable that there is an interdependence of interest between capture fisheries and fish processing business particularly in Barito Kuala District. Since the fish are perishable, the catches should be quickly distributed to fish processing industries and fish markets either for export quotas to generate national income or for local consumption needs. It is recognized that fish processing business sufficiently requires a high level of raw materials in both number and its availability to keep the industry works $[2,3]$. It is generally accepted that small scale fisheries play important role in supporting the development of national and regional economic in terms of food supplier and manpower[4,5]. In the past, fisheries activity is more emphasized to meet production targets (quotas) resulted in fisheries sector as a subsystem of agribusiness that is considered giving less contribution in the added value. Thus, fishery business system is necessarily improved.

The giant featherback (Notopterus chitala, Hamilton-Buchanan 1822) is one of commercially important freshwater fish species in Barito Kuala District due to a great taste and high price. It is locally called "pipih" because of having flat body form (Figure 1). It belongs to family Notopteridae (fish with knifeback).Their unique styling also makes it kept in aquariums as ornamental fish[6].According to Arifudin 
[7], the featherback with medium size reach maximum of $100 \mathrm{~cm}$ length with average weight of $0.5-1 \mathrm{~kg}$, while in nature it can reach up to 2-4 kg of fish. Its body shape is flat with small head size and at the nape of its neck looks hunchback. Maxillary located far behind the eyes, and the body is covered with small scales. Scales on the back is gray while in the belly is silvery white. The sides are white circles as black balls, each surrounded by a white circle. With increasing age, body decoration flat fish will disappear and be replaced by lines of black.

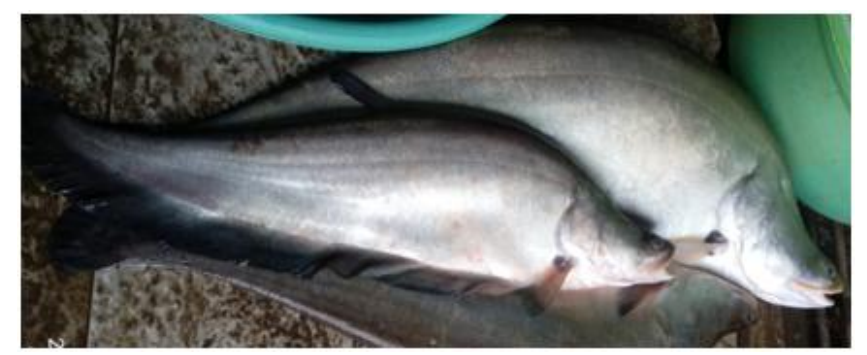

Figure1. Sample of the giant featherback from Barito Kuala District

In Barito Kuala District, the featherback chips processing industry activities have long been growing and lasted for generations. The fisherman and his family members work together to get economic benefit of this household business. Within the last five years, the featherback catch production varied between 16.7 and 394 tons, which absolutely affecting on volume of production and sale price of the fish including fish chips in the markets. Recently, supply and demand of raw material for making the chips is completely dependent on the catch from the rivers. There is a subsequent increased demand of featherback in Barito Kuala that is not only for chips processing industry, but also for other product (e.g. amplang), household consumption and restaurant. The supply of fresh fish for chips making is still low in quantity about 3-4 tons per year. For the time being, there is no commercial fish farming of featherback in this area, so far. This issue should be of great concern to the people and the local authority as a whole to manage fish resource properly and to keep fish processing business sustained. The objective of this research was to investigate the interconnection between capture fishery, fish processing and fish farming prospect in Barito Kuala District, and provide some fundamental recommendations for future research.

\section{Material AND Methods}

\subsection{Study Site}

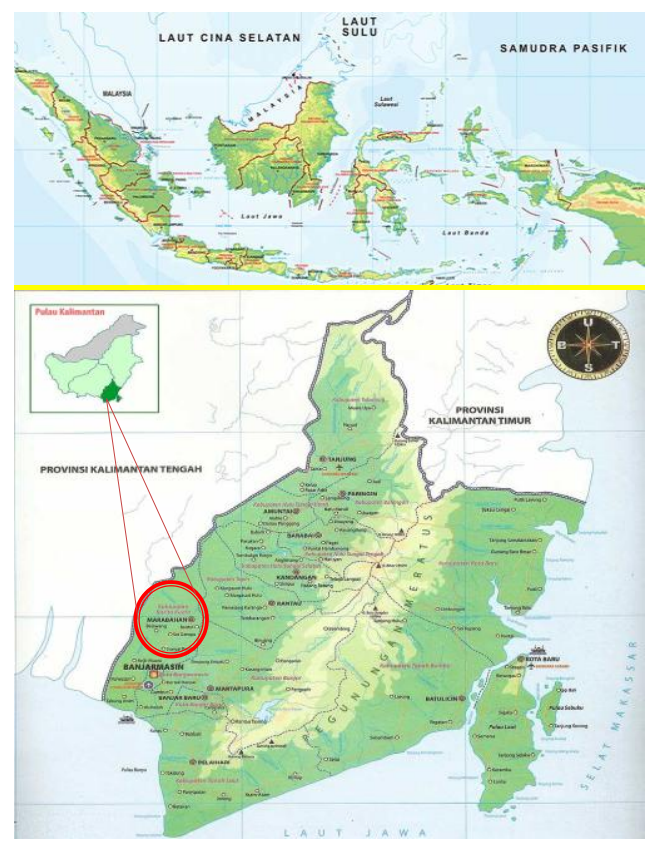

Figure2. The map showing the investigated area in Barito Kuala District, South Kalimantan Province 
The research was carried out in Barito Kuala District (Figure 2), located on 2 $29^{\circ} 50$ "S and 114²0'50"E. The district area is $2,996.96 \mathrm{~km}^{2}$ or $7.99 \%$ of total area of South Kalimantan Province, which covers 16 sub-districts and 200 villages. The district is lowland at 0.2 to $3 \mathrm{~m}$ height above sea level, which is cleared by the Barito River region that stretches from south to north. Like other areas in Indonesia, Barito Kuala has two seasons i.e. dry season, which usually occurs in May to October and rainy season, which usually occurs in November to April. The highest rainfall is $328.2 \mathrm{~mm}$ in December and the lowest rainfall is 62 $\mathrm{mm}$ in September.

\subsection{Data collection and Analysis}

Data on capture fishery such as annual catch production and market prices were obtained from Marine and Fisheries Service of South Kalimantan Province and supported by both local fishermen and extension officers. While information on the existing fish processing business and fish farming obtained from various sources. Data were tabulated and analyzed using descriptive method.

The feasibility of fish processing business can be interpreted by using the following criteria. The market opportunity for featherback chips was determined by calculating the difference between demand and supply of fish chips within a certain time using the simple equation:

$\mathrm{MO}=\mathrm{D}-\mathrm{S}$

Where $\mathrm{MO}=$ market opportunity (ton/year), $\mathrm{D}=$ demand (ton/year), and $\mathrm{S}=$ supply (ton/year).

The market opportunity was expressed as the possibility of fish chips product can lead to higher profits for business. The higher value obtained, the bigger market opportunity to be pursued. Business profit was determined using the formula:

$\pi=\mathrm{TR}-\mathrm{TC}$

Where $\pi=$ business profit, $\mathrm{TR}=$ total revenue, and $\mathrm{TC}=$ total cost. The higher value $\pi$ the greater business profit obtained.

The feasibility of fish chips processing business was analyzed based on investment criteria such as Net Present Value (NPV), Net Benefit Cost Ratio (Net BCR), Internal Rate of Return (IRR) and payback Period (PP) [8]. The interest rate was fixed at $14 \%$ and the life of business for five years. Net Present Value (NPV) is the present value of a business, which is reduced by the cost of business in a given year. If NPV> zero (positive), then business is prioritized to implement. If the size of the NPV equal to zero, it means that the effort to restore the funds for interest rates (social opportunity cost of capital). Meanwhile, if the amount of NPV <zero (negative), then the business should be rejected and also indicate there is any kind of use for other more profitable businesses. The NPV was calculated using the following formula:

$$
N P V=\sum_{t=1}^{n} \frac{\left(B_{t}-C_{t}\right)}{(1+i)^{t}}
$$

Where NPV is net present value, Bt is benefit of year-t, Ct is cost of year-t, $i$ is interest rate, and $t$ is investment time.

Net Benefit Cost Ratio (Net BCR) is a way of evaluating a business by comparing the present value of all results obtained an undertaking by the present value of all costs of business. Net BCR will describe the advantages and feasible if it has a value greater than one or Benefit cost Ratio (BCR) is greater than zero. It was calculated using the formula:

$$
N e t B C R=\frac{\sum_{t=1}^{n} N P V^{+}}{\sum_{t=1}^{n} N P V^{-}}
$$

Where NPV+ is positive net present value and NPV- is negative net present value

Internal Rate of Return (IRR) interest rates which made the business will return all the investment over the life of business. A business will be acceptable if IRR is greater than the opportunity cost of capital, and if otherwise the business will be rejected. 


$$
I R R=i_{1}+\frac{N P V^{+}}{N P V^{+}-N P V^{-}}\left(i_{2}-i_{1}\right)
$$

Where IRR is internal rate of return, NPV+ is positive net present value, NPV- is negative net present value, $i_{1}$ is interest rate when NPV positive and $i_{2}$ is interest rate when NPV negative.

The payback period is a measure of profitability and liquidity [9]. It is generally accepted that investments with shorter payback periods are considered to have lower risk [10,11]. It is also considered reasonable that the shorter the PP, the more liquid and the more viable the business [12].

$$
P P=\frac{\text { InCap }}{\text { AnnualCF }}
$$

Where PP is payback period, InCap is investment value, and Annual CF is annual cash flow. It is assumed that if NPV $<0$, Net $\mathrm{BCR}<1$, IRR $<13 \%$, and $\mathrm{PP}>5$ years indicating the business is unreasonable. Otherwise, if NPV> 0; Net BCR > 1, IRR $>13 \%$, and PP $<5$ years, it is therefore the business is reasonable to be developed.

\section{RESUlTS AND DisCUSSION}

\subsection{Capture Fishery}

Barito Kuala District is the largest producer of the featherback in South Kalimantan Province over the Districts of Tapin, Hulu Sungai Utara, Banjarmasin, Tanah Bumbu, Balangan, Banjar and Hulu Sungai Selatan (Table 1). In the last five years (2014-2018), Barito Kuala District entirely contributes more than $38 \%$ (981.6 tons) of total catch production (2,563.6 tons) with the average annual catch 196.32 tons. The lowest catch production (16.7 tons) was recorded in 2015, and tended to gradually increase by 394 tons in 2018, indicating that the featherback population in nature seemed to be experiencing of equilibrium, as well as shown in other districts. It does not mean local fishermen are allowed freely to increase their fishing efforts for the next year. Therefore, precaution measure to fisheries should be put in place to protect sustainable fish resources. In general there are many factors may influence the fluctuation of catch production over the Districts including inter-river migration, the food availability, water temperature, etc. It is acknowledged that there is a big possibility of the featherback to migrate naturally for foraging and reproduction through inter-territorial waters since the rivers in this region are connected from one to another. It is a great challenge for us in the next study to provide more detailed information on the habitat characteristics of featherback, reproductive process, fishing season, how and why fish migrate, and what obstacles are being faced during migration.

Table1. The annual catch production and the market prices of the featherback fresh fish by Districts in South

\begin{tabular}{|c|c|c|c|c|c|c|}
\hline \multirow{2}{*}{ Districts } & \multicolumn{5}{|c|}{ Production (tons/year) } & \multirow{2}{*}{ Total } \\
\hline & 2014 & 2015 & 2016 & 2017 & 2018 & \\
\hline Barito Kuala & 266 & 16.7 & 103.9 & 201 & 394 & 981.6 \\
\hline Tanah Bumbu & 1.3 & 46.7 & 0.9 & 78 & 92 & 218.9 \\
\hline Banjarmasin & 45.5 & 54.1 & 55.1 & 55.1 & 79.7 & 289.5 \\
\hline Tapin & 76.4 & 63.1 & 127.2 & 176 & 202 & 644.7 \\
\hline Hulu Sungai Utara & 28.6 & 21.8 & 5 & 138 & 148 & 341.4 \\
\hline Balangan & - & 10.9 & - & 16.2 & 15.9 & 43.0 \\
\hline Banjar & 8.5 & 29 & - & - & - & 37.5 \\
\hline Hulu Sungai Selatan & - & 7 & - & - & - & 7 \\
\hline Total & 426.3 & 249.3 & 292.1 & 664.3 & 931.6 & 2563.6 \\
\hline \multirow{2}{*}{ Districts } & \multicolumn{5}{|c|}{$\begin{array}{l}\text { Price (IDR per kg) } \\
\end{array}$} & \multirow{2}{*}{ Total } \\
\hline & 2014 & 2015 & 2016 & 2017 & 2018 & \\
\hline Barito Kuala & 37,650 & 35,000 & 37,733 & 19,505 & 9,950 & 139,838 \\
\hline Tanah Bumbu & 39,296 & 4,703 & 38,333 & 442 & 375 & 83,149 \\
\hline Banjarmasin & 75,000 & 68,628 & 75,000 & 75,000 & 51,894 & 345,522 \\
\hline Tapin & 9,160 & 9,199 & 9,534 & 6,892 & 6,003 & 40,788 \\
\hline Hulu Sungai Utara & 50,524 & 53,673 & 61,834 & 2,240 & 2,089 & 170,360 \\
\hline Balangan & - & 13,303 & 116,337 & 134,290 & 136,824 & 400,754 \\
\hline
\end{tabular}
Kalimantan Province

International Journal of Innovative Studies in Aquatic Biology and Fisheries (IJISABF)

Page $\mid 24$ 
Featherback Fishery In Barito Kuala District, Indonesia: Potency, Business Opportunity And Challenge

\begin{tabular}{|c|c|c|c|c|c|c|}
\hline Banjar & 35,000 & 18,000 & - & - & - & 53,000 \\
\hline Hulu Sungai Selatan & - & 10,021 & - & - & - & 10,021 \\
\hline Total & 246,630 & 212,527 & 338,771 & 238,369 & 207,135 & $1,243,432$ \\
\hline
\end{tabular}

Source: Marine and Fisheries Service, South Kalimantan Province (2019)

In Barito Kuala District, local fishermen used various fishing gears to collect fish from the wild with or without bait, such as lukah (fish traps), tempirai (bamboo-stage trap), pancing (hook and line), lunta (cast net) and rengge (gillnet). These fishing gears were similarly used in other geographical areas [13, 14, and 15]. Since the featherback is considered nocturnal fish species, it is also possibly caught by the light traps $[16,17,18]$, and the results are open for discussion. In case of gill netting, the fishermen from Kaptai Lake, Bangladesh used mesh sizes ranged of 60-140 mm for catching N. notopterus [19]. For selectivity reason, Gustomi et al. [13] suggested to use the mesh size of gillnet at least $30 \mathrm{~mm}$ (1.5 inch) to conserve population of N. Notopterus in Simpur Reservoir, Bangka Island by considering the fish head height at first gonad mature was $19.7 \mathrm{~mm}$ for male and $23.41 \mathrm{~mm}$ for female. The length sizes of $N$. Chitala (327$524 \mathrm{~mm}$ ) sampled from Barito Kuala District was smaller than those of Chitala Lopis (401-950 mm) from Kampar River, Riau Province [20] or N. Chitala $(350-790 \mathrm{~mm})$ from Batanghari River, Jambi Province [21], but it was larger than the sizes of N. notopterus (137-354) $\mathrm{mm}$ from freshwater research center, India [22] or N. Notopterus (120-249 mm) mm from Simpur Reservoir, Bangka District [13]. According to Adjie et al. [21], the featherback had a low fecundity as compared to other fish species, such as snakehead Channa striat a [23], climbing perch Anabas test udineus [24], patin Pangasius hypophthalmus [25], lais Ompok hypophthalmus [26] or Thai catfish Clarias batrachus [27]. Low fecundity was found to be related to the bigger size of eggs, single lobed ovary and the presence of nest building behaviour[28]. Therefore, if fishing activity is unmanaged properly, the fish stock will be depleted and this will have a direct impact on socio-economic as the whole. Mustafa et al. [19] suggested that the value of exploitation rate should be less than $0.50(\mathrm{E}<0.50)$. Since the catch production of featherback is solely sourced from fishing activity, so the local government or fishery manager should take conservation measures such as fishing control (e.g. location, season, type and number of fishing gears used, and fish size may be caught), as well as restocking program to support industrial fish processing for this species (Figure 3).

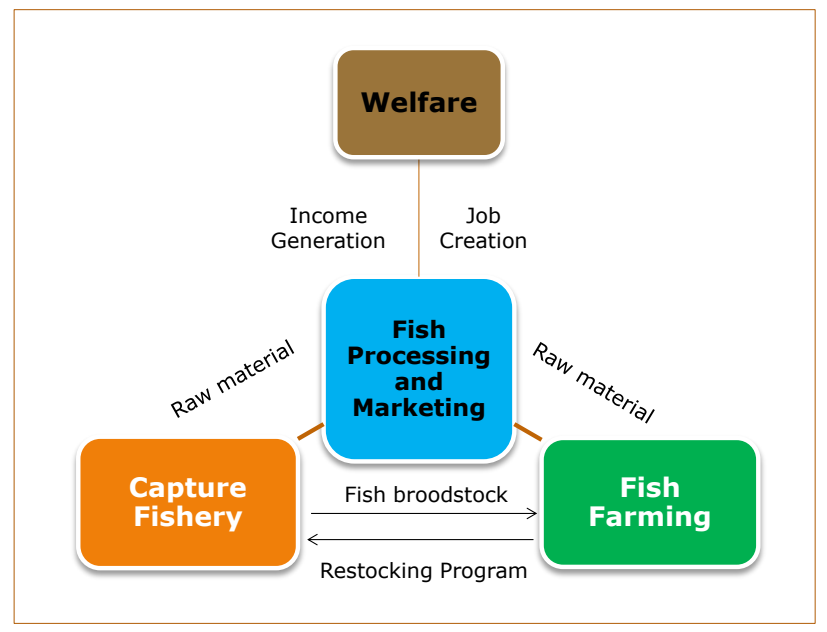

Figure3. The ideal Interconnection of capture fishery, fish processing and fish farming of the featherback in Barito Kuala District.

\subsection{Fish Chips Processing Business}

The fluctuation of the featherback's catch production in Barito Kuala certainly had an impact on the selling price in the market. It is generally accepted that the more catches the cheaper the price of fish, and vice versa. The market prices of featherback within the last five years varied between IDR 9,950 and IDR 37,733 per kg corresponding to the catch production (Table 1). Before this study, the fish chips were sold for IDR 60,000 up to IDR 80,000 per kg; recently they were sold for IDR 120,000 per kg or increase 1.52 times of the former prices. It was a fair and reasonable price as compared to the price for buying fish 
meat as a main raw material that was already high in the market i.e. IDR 140,000 per kg. Such condition was mainly attributable to the fish supply that was highly dependent upon catches from the wild. The change in prices will certainly have an impact on revenues or profits, as well as its business prospect in long term financial viability.

It is also important to note that when the featherback catch are still abundant, the producer can make fish chips about 10-20 kg per cycle with the frequency of 5-10 times per month. It means that the producers can produce fish chips about 50-200 $\mathrm{kg}$ per month. If thirty active producers are able to produce fish chips of $100 \mathrm{~kg}$ per month in average, it means that there are about 3 tons per month or 36 tons per year of fish chips produced from Barito Kuala District. Wahdah et al. [3] roughly estimated that this processing business requires fish meat as raw material by at least 18 tons per year or about 27 tons of fresh fish. The fact the supply of fish meat is only about 4 tons per year (22\%). In other word, this processing business is just able to supply to the market about 6 tons per year while the demand of fish chips reaches about 36 tons per year, indicating that there is open market opportunity for chips processing business. In respond to the raw material shortage, actually the fish producer can buy it from other districts or provinces if the stock is still available, but it will increase operational expenses. A success of fish chips processing business in this region was also due to guidance and continuous support given by both Provincial and District Fisheries Services in the form of fish processing equipment aids such as fish meat grinder, cutting machine, sealer and a freezer as described in Table 2 .

Table2. The featherback fish chips processing business condition before and after getting the aids from Marine and Fisheries Department, South Kalimantan Province

\begin{tabular}{|c|c|c|}
\hline \multirow{2}{*}{ Parameter observed } & \multicolumn{2}{|c|}{ Business Performance } \\
\hline & Before & After \\
\hline $\begin{array}{l}\text { Application of } \\
\text { Technology }\end{array}$ & $\begin{array}{ll}\text { - } & \text { Simple method } \\
\text { - } & \text { Raw materials just carried to the mill } \\
\text { - } & \text { Plastic sealed packaging with fire of } \\
& \text { candle lamp } \\
\text { - } & \text { Packaging with label potluck }\end{array}$ & $\begin{array}{l}\text { - Using machine such as meat } \\
\text { grinder, sealer and freezer } \\
\text { Packaging with a complete label, } \\
\text { such as: composition, trade license, } \\
\text { address production, halal label and } \\
\text { expire date }\end{array}$ \\
\hline Institutional & Independent & Enterprise group incorporated \\
\hline Supervision & None & Marine and Fisheries Department \\
\hline Production: & & \\
\hline - Volume & $5-10 \mathrm{~kg}$ & $10-20 \mathrm{~kg}$ \\
\hline - $\quad$ Frequency & 3 - 5 times & $5-10$ times \\
\hline $\begin{array}{ll}- & \text { Product } \\
& \text { diversification }\end{array}$ & Featherback chips only & $\begin{array}{c}\text { Featherback chips, lemuru chips, and rice } \\
\text { chips }\end{array}$ \\
\hline
\end{tabular}

Source: Wahdah et al. (2016)

Wahdah et al. [3] calculated the monthly profits obtained from fish chips processing business ranging between IDR 574,417 and IDR 1,077,500. The profits received were still below the monthly minimum wage of Barito Kuala District viz. IDR 2,085,050. It was quite reasonable because at that time the producers just capable of making fish chips about 30-50 kg per month due to limited raw material. As time goes by, the profit may increase over the mark corresponding to the catch improvement and market price of featherback. Linked to another product of the featherback e.g.amplang [4], the average annual profit received by the fish chips producers from Barito Kuala District (IDR 12,930,000) was relatively higher than that of amplang producers from Palangka Raya City of Central Kalimantan (IDR 12.169.000). Compared to the snakehead chips processing business in Banjarmasin City of South Kalimantan, Aini [29] reported that the average business profit per unit of production received by producers was IDR 9,846 per $\mathrm{kg}$, which was about two times lower than received by featherback chips producers (IDR 21,799 per $\mathrm{kg}$ ). However, since the snakehead chips producers created more products of $80-480 \mathrm{~kg}$ per month, so that the average monthly business profit obtained was IDR 2,939,583, which was higher than the monthly minimum wage of Banjarmasin City viz. IDR 2,105,000. Hence, the more products sold the higher profits obtained regardless its prices. In addition, to generate more income, the featherback chips producers made innovation by making lemuru chips and rice chips utilizing other types of raw materials which are 
plentiful and cheap. The other way, it is also very possible for them to produce gelatin from the featherback skins especially when the fish are abundantly available. According to Kittiphattanabawon et al. [30], the extracted gelatin from clown featherback skin at $45^{\circ} \mathrm{C}$ for 6 or $12 \mathrm{~h}$ can be a great substitute of commercial bovine gelatin. Various value added products such as proteins, oil, amino acids, minerals, enzymes, bioactive peptides, and collagen can also be yielded from fish processing wastes [31], as well as valuation of economic utilization of fish processing waste[5]. Again, continuous support from Marine and Fisheries Service of Barito Kuala District to create this new business opportunity is necessary. Dealing with the market opportunity, various fish chips products from Barito Kuala District now can be easily found in the home industries, traditional and super markets or the nearest International Syamsudin Noor Airport, South Kalimantan Province.

The feasibility of financial business for featherback chips from Barito Kuala District was much lower than that of Seruyan District, Central Kalimantan (Table 3). For instance, the NPV IRR and Net B/C values of Seruyan's featherback chips were 29 times, 1.6 times and 1.5 times higher than those of Barito Kuala's featherback chips. This because Seruyan's fish chips product $(2,400 \mathrm{~kg} / \mathrm{year})$ was 4 times higher than Barito Kuala's fish chips product $(600 \mathrm{~kg}$ /year). For this reason, Seruyan's producers had shorter Payback Period (5 months 20 days) or 1.6 times faster than Payback Period of Barito Kuala's producers (8 months 15 days). According to Winarti [2], the decrease in production volume or selling price of fish chips was more sensitive as compared to the increase of raw material price.

Table3. Comparative feasibility of financial business for fish chips processing in Barito Kuala District - South Kalimantan and Seruyan District - Central Kalimantan

\begin{tabular}{|c|c|c|c|}
\hline \multirow{2}{*}{ No } & \multirow{2}{*}{ Business Feasibility Criteria } & \multicolumn{2}{|c|}{ The feasibility of financial business } \\
\hline & & Barito Kuala District $^{1}$ & Seruyan District $^{2}$ \\
\hline 1 & Net Present Value (NPV) & IDR $40,304,000$ & IDR $1,177,020,029$ \\
\hline 2 & Internal Rate of Return (IRR) & $137 \%$ & $212.98 \%$ \\
\hline 3 & Net Benefit Cost Ratio (Net B/C) & 4.59 & 7.01 \\
\hline 4 & Payback Period & 8 months 15 days & 5 months 20 days \\
\hline
\end{tabular}

Source: ${ }^{1}$ Wahdah et al. (2016), ${ }^{2}$ Winarti (2016)

\subsection{Fish Farming}

It is reiterated that the featherback production especially in Barito Kuala District is much depending on the catch from the wild. No commercial farming activity for featherback was observed in the investigated area. An effort has been made by the Center for Freshwater Fish Culture of Mandiangin, South Kalimantan to collect the featherback brood stocks from Riam Kanan reservoir. A total of 125 individual brood stocks consisted of 45 females (2-5 kg weight) and 82 males (1.5-5.5 kg weight) have been successfully cultivated and domesticated in the Center. Practically, fish broods can be cultured in the pond of $400 \mathrm{~m}^{2}$ with slow or no water current at 0.7-1 m water depth under control conditions (pH 7.28.2, DO 5.2-6.6 $\mathrm{mm} \mathrm{L}^{-1}$, and NH3 0.01-0.11 $\mathrm{mm} \mathrm{L}^{-1}$ ). Fish were fed with small fresh shrimp of 5-7 \% of body weight twice a day. The featherback is typically nocturnal species; therefore, more feed should be given in the afternoon rather than in the morning. Fish spawned during rainy season from August to March. The fecundity of fish was ranged of 102-566 eggs per individual. The hatching rate and survival rate (SR) of larvae were $72.2 \%$ and $64.2 \%$ respectively. The larvae hatch in about 72-120 hours at 29-30 ${ }^{\circ} \mathrm{C}$. During the first 30 days of culture, from 3,547 seeds reared in the pond, it was yielded about 1,993 seeds (SR $56.3 \%$ ) with the body sizes ranged of $15-17 \mathrm{~cm}$ total length and 10-12 gr weight. Furthermore, fish seeds can be grew-out in the cage by feeding them with trash fish. The similar method is also potentially applicable for the featherback species inhabiting in Barito Kuala River.

Table4. Comparative total length, weight, fecundity, egg diameter, gonadosomatic index (GSI) and ratio of fecundity to body weight (F/W) of family Notopteridae from different geographical areas

\begin{tabular}{|c|c|c|c|c|c|c|c|c|c|}
\hline Locations & Country & Species & $\begin{array}{c}\text { Total } \\
\text { length } \\
(\mathrm{mm})\end{array}$ & $\begin{array}{c}\text { Weight } \\
(\mathrm{g})\end{array}$ & $\begin{array}{c}\text { Fecundi } \\
\text { ty(egg) }\end{array}$ & $\begin{array}{c}\text { Egg } \\
\text { diamet } \\
\text { er(mm) }\end{array}$ & $\begin{array}{c}\text { GSI } \\
\%\end{array}$ & F/W & References \\
\hline Mandiangin & Indonesia & N. chitala & $\begin{array}{c}875- \\
970\end{array}$ & $\begin{array}{c}2,000- \\
7,000\end{array}$ & $102-586$ & $1.5-2.3$ & - & $\begin{array}{c}0.05- \\
0.08\end{array}$ & $\begin{array}{c}\text { Present } \\
\text { study }\end{array}$ \\
\hline
\end{tabular}

International Journal of Innovative Studies in Aquatic Biology and Fisheries (IJISABF)

Page $\mid 27$ 
Featherback Fishery In Barito Kuala District, Indonesia: Potency, Business Opportunity And Challenge

\begin{tabular}{|c|c|c|c|c|c|c|c|c|c|}
\hline $\begin{array}{c}\text { Batanghari } \\
\text { River, } \\
\text { Jambi }\end{array}$ & Indonesia & N. chitala & $\begin{array}{l}350- \\
970\end{array}$ & $\begin{array}{c}800- \\
7,000\end{array}$ & $\begin{array}{c}260- \\
6,080\end{array}$ & $\begin{array}{l}0.15- \\
3.76\end{array}$ & $\begin{array}{c}0.26- \\
1.86\end{array}$ & $\begin{array}{l}2.29- \\
7.22\end{array}$ & $\begin{array}{c}\text { Adjie et al. } \\
1999\end{array}$ \\
\hline $\begin{array}{l}\text { LubukLamp } \\
\text { am, South } \\
\text { Sumatera }\end{array}$ & Indonesia & N. chitala & $\begin{array}{l}810- \\
830\end{array}$ & $\begin{array}{l}1,194- \\
8,320\end{array}$ & $\begin{array}{l}1,194- \\
8,320\end{array}$ & $1.5-3.0$ & - & $\begin{array}{l}1.47- \\
10.02\end{array}$ & $\begin{array}{l}\text { Adjie and } \\
\text { Utomo, } \\
1994\end{array}$ \\
\hline $\begin{array}{c}\text { Simpur } \\
\text { Reservoir, } \\
\text { Bangka } \\
\text { Island }\end{array}$ & Indonesia & $\begin{array}{c}N . \\
\text { notopterus }\end{array}$ & $\begin{array}{l}155- \\
240\end{array}$ & $\begin{array}{l}48.44- \\
105.15\end{array}$ & $\begin{array}{l}1,051- \\
6,057\end{array}$ & $\begin{array}{c}1.05- \\
2.2\end{array}$ & $\begin{array}{l}1.84- \\
16.52\end{array}$ & $\begin{array}{c}21.72 \\
- \\
57.60\end{array}$ & $\begin{array}{l}\text { Gustomi et } \\
\text { al. } 2016\end{array}$ \\
\hline $\begin{array}{c}\text { Keenjhar } \\
\text { Lake, Sindh }\end{array}$ & Pakistan & $\begin{array}{c}N . \\
\text { notopterus }\end{array}$ & $\begin{array}{l}185- \\
305\end{array}$ & $\begin{array}{l}66.5- \\
313.8\end{array}$ & $\begin{array}{c}105- \\
1,500\end{array}$ & $\begin{array}{l}1.0- \\
2.82\end{array}$ & $\begin{array}{l}3.72- \\
7.92\end{array}$ & $\begin{array}{l}2.26- \\
4.78\end{array}$ & $\begin{array}{l}\text { Chandio et } \\
\text { al. } 2016\end{array}$ \\
\hline $\begin{array}{c}\text { Humboldt } \\
\text { Univ. of } \\
\text { Berlin }\end{array}$ & Germany & $\begin{array}{c}N . \\
\text { notopterus }\end{array}$ & $\begin{array}{l}216- \\
270\end{array}$ & $\begin{array}{c}82.15- \\
133.8\end{array}$ & $15-225$ & $3.8-4.0$ & - & $\begin{array}{l}0.18- \\
1.68\end{array}$ & $\begin{array}{l}\text { Yanwirsal } \\
\text { et al. } 2017\end{array}$ \\
\hline $\begin{array}{l}\text { Killa Fish } \\
\text { Farm }\end{array}$ & India & $\begin{array}{c}N . \\
\text { notopterus }\end{array}$ & $\begin{array}{l}200- \\
391\end{array}$ & $57-220$ & $\begin{array}{l}175- \\
1,180\end{array}$ & $\begin{array}{l}2.61- \\
3.04\end{array}$ & $\begin{array}{l}0.70- \\
6.00\end{array}$ & $\begin{array}{l}3.07- \\
5.36\end{array}$ & $\begin{array}{l}\text { Parameswa } \\
\text { ran and } \\
\text { Sinha, } 1966\end{array}$ \\
\hline $\begin{array}{l}\text { Modhumoti } \\
\text { river }\end{array}$ & $\begin{array}{c}\text { Banglades } \\
\mathrm{h}\end{array}$ & N. chitala & $\cdots$ & $\begin{array}{c}4,200- \\
5,000\end{array}$ & $\begin{array}{l}1,580- \\
9,800\end{array}$ & 4.58 & $\begin{array}{l}3.50- \\
8.10\end{array}$ & $\begin{array}{c}0.38- \\
1.96 \\
\end{array}$ & $\begin{array}{l}\text { Hossain et } \\
\text { al. } 2006\end{array}$ \\
\hline $\begin{array}{c}\text { Gomti } \\
\text { River, } \\
\text { Lucknow }\end{array}$ & India & $\begin{array}{c}N . \\
\text { notopterus }\end{array}$ & $\begin{array}{l}180- \\
349\end{array}$ & $42-350$ & $\begin{array}{c}140- \\
1,392\end{array}$ & $\cdots$ & - & $\begin{array}{l}3.33- \\
3.98\end{array}$ & $\begin{array}{l}\text { Srivastava } \\
\text { et al. } 2012 \text {. }\end{array}$ \\
\hline $\begin{array}{c}\text { Mymensing } \\
\mathrm{h}\end{array}$ & $\begin{array}{l}\text { Banglades } \\
\mathrm{h}\end{array}$ & $\begin{array}{c}N . \\
\text { notopterus }\end{array}$ & $\begin{array}{c}539- \\
676.5\end{array}$ & $\begin{array}{l}1,178- \\
2,041\end{array}$ & $\begin{array}{l}8,238- \\
18,569\end{array}$ & $\begin{array}{l}0.04- \\
4.00\end{array}$ & $\begin{array}{l}0.20- \\
4.63\end{array}$ & $\begin{array}{l}6.99- \\
9.10\end{array}$ & $\begin{array}{l}\text { Kohinoor et } \\
\text { al. } 2012\end{array}$ \\
\hline
\end{tabular}

The knowledge of fish reproduction is the most important in sustainable fisheries management, as well as to sustain fish processing business especially in Barito Kuala District. Numerous studies closely related to the featherback have been devoted to describe on reproductive biology [13,32,33], fecundity[6,34,35], genetic [36,37], length-weight relationship and condition factor[15,38], feeding habits $[39,40]$, the age and growth [41], population dynamics [19], culture strategy[42,43] and conservation measures for this species [20,44]. In addition, Wibowo and Marson [37] reported that morphometric and meristic of $N$. chitala from Barito River, South Kalimantan were similar to those of C. lopis and N. notopterus from Kampar River, Riau Province, but genetically different from each other. The phenomenon of nonidentical genetic inter-organisms along the rivers has also been well-documented in $N$. notopterus collected from the Mekong River, Cambodia [45] and Macrobrachium nipponense from the Yangtze and Lancang Rivers, China [46].

Since there is no commercial fish farming for featherback in this region, we strongly recommend the BBI Bakambat Barito Kuala (local fish hatchery center of Bakambat) starts collecting the featherback fish broods directly from Barito Kuala River including its water quality parameters. After all, release fish larvae back to the blocked river or swamp forest and monitor for survival and growth rates of the fish. The featherback living in Barito River is adaptive to acidiferous waters condition. Hence, the treatment and result may have a difference of the featherback living in Riam kanan Reservoir. In addition, Gustomi et al. [13] reported that the featherback was a typically partial spawner, and the maturity gonad of male was faster than female. For future research, it is also necessary to collect more individuals of the featherback from Barito Kuala River to investigate the length-weight relationship and relative condition factor of this species. This scientific information is needed for better fisheries management since the featherback population tends to decline over the last few years.

It can be pointed out that currently the featherback fishery beneficially supports the fish chips processing business in supplying raw material for home industry. However, it is not a long-term solution for business. Fish farming practice is the best business that can provide many profitable opportunities today and future particularly in creating job opportunities and generating more income businesses (Figure 3), as well as to support conservation measures and restocking program for sustainable fisheries resource management in this region. 


\section{ACKNOWLEDGMENT}

This research was funded by Lambung Mangkurat University. Thanks to Mrs. NurulIzzati, Fisheries Extension Officer, who helped us during field work to be our gratitude goes to the reviewers for significantly improving the contents of manuscript to publishable level.

\section{REFERENCES}

[1] BPS-Statistics of Barito Kuala Regency.(2017). Barito Kuala Regency in Figures'. 336.

[2] Winarti, L. (2016). Sensitivity Analysis of flat fish cracker processing business in SeruyanHilir sub District of Seruyan Regency. ZIRAA'AH. 41(2): 177-182

[3] Wahdah, Mahreda, E.S. and Lilimantik, E. (2016). Study of the feasibility of the giant Featherback cracker processing business in Barito Kuala Regency South Kalimantan. EnviroScientae. 12(2): 113-119.

[4] Evi, S.U., Mahreda, E.S. and Dekayanti, T. (2012). Analysis usahapengolahanamplangikanpipih (Notopteruschilata) skalarumahtangga di Kota Palangka Raya Provinsi Kalimantan Tengah. Fish Scientiae. 2(3): 64-74.

[5] Marnis, Syahrul, Fitri and Mardayulis. (2016). Valuation of economic utilization of fish processing waste Patin (Pangasiushypopthalmus) as an added value for fish processing industry players in the District Kampar, Riau. International Journal of Economics and Finance. 8(9): 104-116. https://doi.org/10.5539/ijef.v8n9p104

[6] Yanwirsal, H., Bartsch, P. and Kirschbaum, F. (2017). Reproduction and development of the Asian bronze featherback Notopterusnotopterus (Pallas, 1769) (Osteoglossiformes, Notopteridae) in captivity. Zoosystematics and Evolution. 93(2): 299-324. http://dx.doi.org/10.3897/zse.93.13341

[7] Arifudin.R. (1983).IkanBelidahewanlangka yang dilindungi. BalaiPengkajianTeknologiPertanian (BPTP), Palembang.

[8] Izmaniar, H., Mahyudin, I., Agusliani, E. and Ahmadi.(2018). The Business prospect of Climbing Perch fish farming with Biofloc Technology at De' Papuyu Farm Banjarbaru. International Journal of Environment, Agriculture and Biotechnology. 3(3): 1145-1153.

[9] Hajdasinski, M.M. (1993).The payback period as a measure of profitability and liquidity. Engineering Economy. 38(3): 177-191. https://doi.org/10.1080/00137919308903096

[10] Lin, H.J. (2010). Why should managers like Payback Period? 2010. Available at SSRN: https://ssrn.com/abstract=1688730 or http://dx.doi.org/10.2139/ssrn.1688730. Accessed on 15 September, 2019.

[11] Lohmann, J.R. and Baksh, S.N. (1993).The IRR, NPV and Payback period and their relative performance in common capital budgeting decision procedures for dealing with risk. Engineering Economy. 39(1): 17-47. https://doi.org/10.1080/00137919308903111

[12] Kim, B.C., Shim, E. and Reinschmidt, K.F. (2013). Probability distribution of the project payback period using the equivalent cash flow decomposition. Engineering Economy. 58(2): 112-136. https://doi.org/10.1080/0013791X.2012.760696

[13] Gustomi, A., Sulistiono and Yonvitner.(2016). Reproductive biology of featherback (Notopterusnotopterus Pallas, 1769) in Simpur Reservoir, Bangka Island. Jurnalllmu Pertanian Indonesia. 21(1): 5662. http://dx.doi.org/10.18343/jipi.21.1.56

[14] Irhamsyah, Ahmadi and Rusmilyansari.(2017). Fish and fishing gears of the Bangkau Swamp, Indonesia.Journal of Fisheries. 5(2): 489-496. http://dx.doi.org/10.17017/jfish.v5i2.2017.223

[15] Kaur, V. and Rawal, Y.K. (2017).Length-weight relationship (LWR) in Notopterusnotopterus (Pallas) from Sukhna Lake, Chandigarh. IOSR Journal of Pharmacy and Biological Sciences. 12(4): 63-65.

[16] Ahmadi. (2012).An introduction of light traps for sampling freshwater shrimp and fish in the Barito River, South Kalimantan. Journal of Fisheries and Aquatic Sciences. 7(2): 173-182. https://doi.org/10.3923/jfas.2012.173.182

[17] Ahmadi and Rizani, A. (2013). Light traps fishing in Sungai Sipai flood swamp of Indonesia: Recommendations for future study. Kasetsart University Fisheries Research Bulletin. 37(2): 17-30.

[18] Aminah, S. and Ahmadi. (2018). Experimental fishing with LED light traps for Three-spot gourami (Trichogastertrichopterus) in Martapura, Indonesia. International Journal of Fisheries and Aquatic Studies. 6(1): 37-42.

[19] Mustafa, M.G., Singha, S., Islam, M.R. and Mallick, N. (2014). Population dynamics of Notopterusnotopterus (Pallas, 1769) from the Kaptai Reservoir of Bangladesh. SAARC Journal of Agriculture. 12(2): 112-122. 
[20] Wibowo, A., Ridwan, A., Kadarwan, S. and Sudarto.(2010).PengelolaansumberdayaikanBelida (Chitalalopis) di Sungai Kampar, Provinsi Riau.JurnalKebijakanPerikanan Indonesia. 2(2): 79-89.

[21] Adjie, S., Husnah and Gaffar, A.K. (1999).Studibiologiikanbelida (Notopteruschitala) di daerahaliran Sungai Batanghari, Propinsi Jambi.JurnalPenelitianPerikanan Indonesia. 5(1): 38-43. https://doi.org/10.15578/jppi.5.1 $.1999 .38-43$

[22] Parameswaran, S. and Sinha, M. (1966). Observations on the biology of the feather-back, Notopterusnotopterus (Pallas). Indian Journal of Fisheries. 13(1\&2): 232-250

[23] Anwar, K., Bijaksana, U., Herliwati and Ahmadi.(2018).Oodev injection frequency and time period in advancing gonad rematuration of Snakehead (ChannastriataBlkr) in hapa system. International Journal of Environment, Agriculture and Biotechnology.3 (3): 1114-1122.

[24] Uddin, S., Hasan, M.H., Iqbal, M.M. and Hossain, M.A. (2017). Study on the reproductive biology of Vietnamese climbing perch (Anabas testudineus, Bloch). Punjab University Journal of Zoology. 32(1): 1-7.

[25] Agustinus.(2016). Reproduction performance by injection oodev on Vitelogenesis at rematuration of catfish (Pangasiushypophthalmus) broodstock in fish farming pond.Fisheries Sciences. 3(5): 1-16.

[26] Elvyra, R., Dedy, D.S., Ridwan, A. and Zairin, J. (2010).KajianaspekreproduksiikanLaisOmpokhypophthalmus di Sungai Kampar, KecamatanLanggam, KabupatenPelalawan, Provinsi Riau. Jurnal Nature Indonesia. 12(2): 117-123.

[27] Zairin,M.Jr. (2000). Annual changes in ovarian maturity of female Thai catfish (Clariasbatrachus) reared in a culture pond. BIOTROPIA. 15: 48-57.

[28] Azadi, M.A., Islam, M.A., Nasiruddin, M. and Quader, M.F. (1995).Productivily biology of Notopterusnotopterus (Palias) in Kaplai reservoir, Bangladesh. Bangladesh Journal of Zoology. 23(2): 215-220.

[29] Aini.M. (2014).AnalisisusahapengolahankerupukikanGabus (ChannastriataBloch).Tesis. Program Studi Magister IlmuPerikanan Program Pascasarjana, University as Lambung Mangkurat, Banjarbaru.

[30] Kittiphattanabawon, P., Benjakul, S., Sinthusamran, S. and Kishimura, H. (2016). Gelatin from clown featherback skin: Extraction conditions. LWT - Food Science and Technology. 66: 186-192. http://dx.doi.org/10.1016/j.lwt.2015.10.029

[31] Ghaly, A.E., Ramakrishnan, V.V., Brooks, M.S., Budge, S.M. and Dave, D. (2013). Fish processing wastes as a potential source of proteins, amino acids and oils: A Critical Review. Microbial and Biochemical Technology. 5(4): 107-129. http://dx.doi.org/10.4172/1948-5948.1000110

[32] Chakrabarti, P. and Chowdhury, S.H. (2014).Annual cyclical changes in the histological Features and surface ultra structure in ovaries of the freshwater Featherback Notopterusnotopterus (Pallas, 1769).Proceeding of Zoology Society. 67(2): 158-166.

[33] Chandio, M.H., Narejo, N.T., Jalbani, S. and Khan, P. (2016). Breeding biology of featherback Notopterousnotopterus from Keenjhar Lake, District Thatta, Sindh, Pakistan. Pakistan Journal of Nutrition. 15(6): 547-550. https://doi.org/10.3923/pjn.2016.547.550

[34] Hossain, Q.Z., Hossain, M.A. and Parween, S. (2006). Breeding biology, captive breeding and fry nursing of humped featherback (Notopteruschitala, Hamilton-Buchanan, 1822). Ecoprint.13: 41-47.

[35] Srivastava, S.M., Shivesh, P., Singh, K. and Pandey, A.K. (2012).Fecundity of threatened Bronze featherback, Notopterusnotopterus (Pallas) from River Gomti, Lucknow (India). National Journal of Life Science. 9(2): 193-200.

[36] Sodsuk, P.K. and Sodsuk, S. (2000). Genetic diversity of featherback fish in Thailand. Kasetsart Journal of Nature Sciences. 34(2): 227-239.

[37] Wibowo, A. and Marson. (2012) phenotypic plasticity phenomenon of giant featherback (Chitalalopis) in Kampar River, Riau. BAWAL. 4(3): 195-204.

[38] Kumar, K.H. and Kiran, B.R. (2016).Relative condition factor of feather back, NotopterusNotopterus (Pallas) from Jannapura pond, BhadravathiTaluk, Karnataka. International Journal of Scientific Research in Science, Engineering and Technology. 2(1): 36-39.

[39] Sarkar, U.K., Lakra, W.S., Deepak, P.K., Negi, R.S., Paul, S.K. and Srivastava, A. (2006). Performance of different types of diets on experimental larval rearing of endangered Chitalachitala (Hamilton) in recirculatory system. Aquaculture. 261: 141-150.

[40] Wibowo, A., Affandi, R. and Atminarso, D. (2014). Food composition and niche characteristic of giant featherback (Chitalalopis, Bleeker 1851) in Kampar River, Indonesia. Indonesian Fisheries Research Journal. 20(1): 1-10. 
[41] Azadi, M.A., Mahamood, N. and Shafi, M. (1994). Studies on the age and growth of Chital, Notopteruschitala (Ham.) from the Kaptai reservoir, Bangladesh. Chittagong University Study. 18(2): 197-205.

[42] Samad, M.A., Farjana, M., Chatterjee, S.K., Rahman, M.M. and Barman, S.C. (2017).Culture technique of endangered Notopteruschitala (Hamilton, 1822) with Oreochromisniloticus for domestication in pond habitat. Bangladesh Journal of Scientific and Industrial Research.52 (3): 187-194. http://dx.doi.org/10.3329/bjsir .v52i3.34154.

[43] Mitra, A., Mukhopadhyay, P.K. and Homechaudhur, I.S. (2018).An overview of biology and culture potentials of Humped featherback Chitalachitala (Hamilton, 1822) - A new candidate for aquaculture diversification. Reviews in Fisheries Science and Aquaculture. 26(3): 371-380. https://doi.org/10.1080/23308249.2018. 1437118

[44] Srivastava, S.M., Srivastava, P.P., Dayal, R., Pandey, A.K. and Singh, S.P. (2010). Induced spawning of captive stock of threatened bronze featherback, Notopterusnotopterus, for stock improvement and conservation. Journal of Applied Bioscience. 36(2): 144-147.

[45] Takagi, A.P., Ishikawa, S., Nao, T., Hort, S., Nakatani, M., Nishida, M. and Kurokura, H. (2006). Genetic differentiation of the bronze featherbackNotopterusnotopterusbetween Mekong River and Tonle Sap Lake population by mitochondrial DNA analysis. Fisheries Sciences. 72: 750-754.

[46] Ping, Y., Hao, Z., Li-qiao, C., Jin-yun, Y., Na, Y., Zhi-min, G. and Da-xiang, S. (2007). Genetic structure of the oriental river prawn (Macrobrachiumnipponense) from Yangtze and Lancang River, inferred from COI gene sequence. Zoological Research. 28(2): 113-118.

Citation: Ahmadi, et.al, "Featherback Fishery in Barito Kuala District, Indonesia: Potency, Business Opportunity and Challenge". International Journal of Innovative Studies in Aquatic Biology and Fisheries, 5(4), pp.2131.http://dx.doi.org/10.20431/2454-7670.0504005

Copyright: () 2019 Authors. This is an open-access article distributed under the terms of the Creative Commons Attribution License, which permits unrestricted use, distribution, and reproduction in any medium, provided the original author and source are credited. 